\title{
One-year monitoring of airborne radionuclides in Wako, Japan, after the Fukushima Dai-ichi nuclear power plant accident in 2011
}

\author{
H. HABA,* J. KanAYA, H. MuKai, T. Kambara and M. Kase \\ Nishina Center for Accelerator-Based Science, RIKEN, Wako, Saitama 351-0198, Japan
}

(Received April 6, 2012; Accepted June 3, 2012)

\begin{abstract}
Airborne radionuclides from the accident of Fukushima Dai-ichi Nuclear Power Plant (FDNPP) in 2011 were measured at the RIKEN Wako Institute, Japan, about $220 \mathrm{~km}$ to the southwest of FDNPP, from March 15, 2011 to March 16, 2012. Radioactivity concentrations of ${ }^{140} \mathrm{Ba},{ }^{137} \mathrm{Cs},{ }^{136 \mathrm{~g}} \mathrm{Cs},{ }^{134 \mathrm{~g}} \mathrm{Cs},{ }^{133 \mathrm{~g}} \mathrm{I},{ }^{132} \mathrm{Te},{ }^{131} \mathrm{I},{ }^{129 \mathrm{~m}} \mathrm{Te},{ }^{110 \mathrm{~m}} \mathrm{Ag}$, ${ }^{99} \mathrm{Mo}$, and ${ }^{95 \mathrm{~g}} \mathrm{Nb}(\mathrm{m}$ : metastable state; g: ground state) were determined by $\gamma$-ray spectrometry with a germanium detector. The time variations of the radioactivity concentrations and their ratios in Wako are discussed by referring to those of the ambient effective dose rate as well as the amount of rainfall. The pronounced peaks of the radioactivity concentrations were observed on March 15, 20-21, and 29-31, 2011. The highest concentrations for typical radionuclides in unit $\mathrm{Bq} \mathrm{m}^{-3}$ were $8.8 \pm 0.2$ for ${ }^{137} \mathrm{Cs}, 1.2 \pm 0.2$ for ${ }^{136 \mathrm{~g}} \mathrm{Cs}, 8.5 \pm 0.2$ for ${ }^{134 \mathrm{~g}} \mathrm{Cs}, 4.7 \pm 0.3$ for ${ }^{133 \mathrm{~g}} \mathrm{I}, 58 \pm 2$ for ${ }^{132} \mathrm{Te}, 8.0 \pm 1.2$ for ${ }^{129 \mathrm{~m}} \mathrm{Te}$, and $35 \pm 1$ for ${ }^{131} \mathrm{I}$ in the sample collected in the period of March 15, 2011, 11:15-11:45 JST (Japan Standard Time). The ${ }^{134 \mathrm{~g}} \mathrm{Cs} /{ }^{137} \mathrm{Cs}$ radioactivity ratio was determined to be $1.0 \pm 0.1$ for March 11, 2011, and this value was consistent with other observations related to the FDNPP accident. The environmental radioactive contamination in Wako occurred mainly on March 21 , 2011, due to the first rainfall after the accident.
\end{abstract}

Keywords: Fukushima Dai-ichi nuclear power plant accident, airborne radionuclide, ${ }^{131} \mathrm{I},{ }^{137} \mathrm{Cs},{ }^{134 \mathrm{~g}} \mathrm{Cs}$

\section{INTRODUCTION}

On March 11, 2011, a great earthquake of magnitude 9.0 occurred near the east coast of Honshu, Japan, and was followed by a large tsunami. The disasters caused damage to the Fukushima Dai-ichi nuclear power plant (FDNPP), resulting in the release of radionuclides into atmosphere and ocean. Chino et al. (2011) applied a reverse estimation method by coupling environmental monitoring data with atmospheric dispersion simulations to calculate release rates of ${ }^{131} \mathrm{I}$ and ${ }^{137} \mathrm{Cs}$ into the atmosphere. They reported that before March 14, 2011, the release rates of $10^{13}-10^{14} \mathrm{~Bq} \mathrm{~h}^{-1}$ of ${ }^{131} \mathrm{I}$ probably correspond to the wetwell venting as well as the hydrogen explosions at FDNPP Units 1 and 3. A significant increase to $10^{16}$ $\mathrm{Bq} \mathrm{h}^{-1}$ of ${ }^{131} \mathrm{I}$ on March 15 was probably caused by the damage of the suppression chamber of Unit 2. From March 16 to 24, the release rate of ${ }^{131} \mathrm{I}$ was on the order of $10^{14} \mathrm{~Bq} \mathrm{~h}^{-1}$ and after March 25, declined to the order of $10^{11}-10^{12} \mathrm{~Bq} \mathrm{~h}^{-1}$ in the beginning of April. The release rate of ${ }^{137} \mathrm{Cs}$ had a similar trend with fluctuations of the ${ }^{131} \mathrm{I} /{ }^{137} \mathrm{Cs}$ radioactivity ratio in the range from 1 to 100 . The total amounts of ${ }^{131} \mathrm{I}$ and ${ }^{137} \mathrm{Cs}$ discharged into the

*Corresponding author (e-mail: haba@riken.jp)

Copyright (c) 2012 by The Geochemical Society of Japan. atmosphere were evaluated to be $1.5 \times 10^{17} \mathrm{~Bq}$ and $1.2 \times$ $10^{16} \mathrm{~Bq}$, respectively, from March $1210: 00^{\dagger}$ to April 6 0:00.

Immediately after the announcement of the FDNPP accident, worldwide monitoring activities started. Major radionuclides such as ${ }^{131} \mathrm{I},{ }^{137} \mathrm{Cs}$, and ${ }^{134} \mathrm{Cs}$ were detected in Japan, e.g., at the monitoring stations in Chiba on March 15 (Amano et al., 2012) and in Fukuoka on March 17 (Momoshima et al., 2012). They were then transported with westerly winds to across the pacific and reached North American continent on March 15 (Diaz Leon et al., 2011; Zhang et al., 2011; Biegalski et al., 2012) and further reached to Europe on March 19-20 (Masson et al., 2011) despite dispersion and deposition along the route of the radioactive plumes. The plumes also arrived at nearby Asian countries such as Taiwan (Huh et al., 2012) on March 25, Vietnam (Long et al., 2012) on March 27, and Korea (Kim et al., 2012) on March 28. Huh et al. (2012) suggested that the radionuclides were transported to Taiwan and its vicinity via two pathways at different altitudes: one was transported in the free troposphere by the prevailing westerly winds around the globe, and the other was transported in the planetary boundary layer by the northeast monsoon wind directly to Taiwan.

\footnotetext{
†Japan Standard Time (JST) is consistently used in this paper; JST = UTC (Universal Time, Coordinated) $+9 \mathrm{~h}$.
} 
On March 15, at the RIKEN Wako Institute, Wako, Japan, located about $220 \mathrm{~km}$ to the southwest of FDNPP, we observed a rapid increase of the effective dose rate from usual $\sim 0.03 \mu \mathrm{Sv} \mathrm{h}^{-1}$ at 4:00 to $1.2 \mu \mathrm{Sv} \mathrm{h}^{-1}$ at 10:00. Hence, we initiated urgent measurement of airborne radionuclides by $\gamma$-ray spectrometry with a germanium detector. In this paper, we present the results of the radioactivity measurement of airborne ${ }^{140} \mathrm{Ba},{ }^{137} \mathrm{Cs},{ }^{136 \mathrm{~g}} \mathrm{Cs}$, ${ }^{134 \mathrm{~g}} \mathrm{Cs},{ }^{133 \mathrm{~g}} \mathrm{I},{ }^{132} \mathrm{Te},{ }^{131} \mathrm{I},{ }^{129 \mathrm{~m}} \mathrm{Te},{ }^{110 \mathrm{~m}} \mathrm{Ag},{ }^{99} \mathrm{Mo}$, and ${ }^{95 \mathrm{~g}} \mathrm{Nb}^{*}$ in Wako during the period from March 15, 2011 to March 16,2012 . The present data, together with the measurements from other monitoring stations, will provide further information on the characteristics of the FDNPP accident such as damages of the nuclear reactor, fuel condition, release and transport of radionuclides. For example, the Tokyo metropolitan area extends between Wako and Chiba, and the monitoring results at Chiba were available from Japan Chemical Analysis Center (JCAC) (latitude $35^{\circ} 39^{\prime} 41^{\prime \prime}$ north and longitude $140^{\circ} 8^{\prime} 12^{\prime \prime}$ east), located about $220 \mathrm{~km}$ to the south-southwest of FDNPP (Amano et al., 2012; Nagaoka et al., 2012), and those results would offer rough estimation of the airborne radioactivity in the area.

\section{Measurement TeChNiques}

Air dust was collected using a commercially available low-volume air dust sampler (M\&F Enterprise SP30) placed on the roof of the Nishina building of the RIKEN Wako Institute, Wako, Japan (latitude 35 $46^{\prime} 44^{\prime \prime}$ north and longitude $139^{\circ} 36^{\prime} 54^{\prime \prime}$ east, $4.3 \mathrm{~m}$ above ground). The sampling flow rate was regulated to $30 \mathrm{~L} \mathrm{~min}^{-1}$ during the air dust collection. A cellulose glass-fiber filter (ADVANTEC HE-40T) was used, and the linear air velocity of the air sampler was $40 \mathrm{~cm} \mathrm{~s}^{-1}$. The collection efficiencies of the filter are reported to be $99.7 \%, 99.8 \%$, and $99.9 \%$ for polystyrene latex particles of $0.31-\mu \mathrm{m}$ diameter at the air velocities of 55,80 , and $135 \mathrm{~cm} \mathrm{~s}^{-1}$, respectively, by the manufacturer. No activated carbon filter was used; hence, our measurements were only sensitive to radionuclides attached to particle matter and were not sensitive to gaseous iodine. The exact collection periods are listed for each filter sample in Supplementary Materials, Table A1. Dust was collected for $30 \mathrm{~min}$ for the first two samples in the periods March 15 11:15-11:45 (F01) and March 16 13:15-13:45 (F02). After the third sample from March 16 18:32 to March 17 9:00 (F03), dust was continuously collected for about one year (F04F86), except for short interruptions due to the filter change

*The letter "m" in ${ }^{129 \mathrm{~m}} \mathrm{Te}$ and ${ }^{110 \mathrm{~m}} \mathrm{Ag}$ denotes the metastable state of the nucleus, and " $\mathrm{g}$ " in ${ }^{136 \mathrm{~g}} \mathrm{Cs},{ }^{134 \mathrm{~g}} \mathrm{Cs}$, ${ }^{133 \mathrm{~g}} \mathrm{I}$, and ${ }^{95 \mathrm{~g}} \mathrm{Nb}$ denotes the ground state since the nuclei have also metastable states. and the cleaning of the sample holder. The filter samples were subjected to $\gamma$-ray spectrometry using a Ge detector with a relative efficiency of $40 \%$ (ORTEC GEM-40190). The detector exhibited an energy resolution of $1.9 \mathrm{keV}$ full width at half maximum (FWHM) at $1332.5 \mathrm{keV}$. The detector was placed in an underground laboratory of the Nishina Building (14.5 m below ground), and was surrounded with $150-\mathrm{mm}$ lead, so that the effective shielding of cosmic-rays enabled us to reduce the background in the $\gamma$-ray spectrometry. The detector efficiency was calibrated with an accuracy of 2-10\% using a multiple $\gamma$ ray standard source $\left({ }^{109} \mathrm{Cd},{ }^{57} \mathrm{Co},{ }^{139 g} \mathrm{Ce},{ }^{51} \mathrm{Cr},{ }^{85 \mathrm{~g}} \mathrm{Sr},{ }^{137} \mathrm{Cs}\right.$, ${ }^{54} \mathrm{Mn},{ }^{88} \mathrm{Y}$, and ${ }^{60 \mathrm{~g}} \mathrm{Co}$ ) with the same size as the filter sample. A calibrated ${ }^{134 \mathrm{~g}} \mathrm{Cs}$ source was also used to correct for the coincidence summing for radioactivity determinations of ${ }^{134 \mathrm{~g}} \mathrm{Cs}$.

The ambient effective dose rate at the Nishina Building was continuously monitored with a sodium iodide (NaI) scintillation detector system (Hitachi Aloka Medical, MAR-R17-2483-1R1) at a height of $1.5 \mathrm{~m}$ above ground level. The amount of rainfall was also automatically registered with a tipping-bucket rain gauge (Ogasawara Keiki, RS-102-N1) in the same campus.

\section{RESULTS}

In the $\gamma$-ray spectra obtained in this work, radionuclides of ${ }^{140} \mathrm{La},{ }^{140} \mathrm{Ba},{ }^{137} \mathrm{Cs},{ }^{136 \mathrm{~g}} \mathrm{Cs},{ }^{134 \mathrm{~g}} \mathrm{Cs},{ }^{133 \mathrm{~g}} \mathrm{I}$, ${ }^{132 \mathrm{~g}} \mathrm{I},{ }^{132} \mathrm{Te},{ }^{131} \mathrm{I},{ }^{131 \mathrm{~m}} \mathrm{Te},{ }^{131 \mathrm{~g}} \mathrm{Te},{ }^{129 \mathrm{~m}} \mathrm{Te},{ }^{129 \mathrm{~g}} \mathrm{Te},{ }^{110 \mathrm{~m}} \mathrm{Ag}$, ${ }^{99 \mathrm{~m}} \mathrm{Tc},{ }^{99} \mathrm{Mo}$, and ${ }^{95 \mathrm{~g}} \mathrm{Nb}$ were identified based on their characteristic $\gamma$-ray energies and half-lives (Firestone and Shirley, 1996; Browne and Firestone, 1986) as listed in Table 1. Figure 1 shows a typical $\gamma$-ray spectrum of the sample collected in the period of March 29 9:40-March 30 11:15 (F16). The filter sample was measured for 35866 $\mathrm{s}$, starting at $1353 \mathrm{~s}$ after the end of the air dust sampling. In Fig. 1, the photopeaks of volatile ${ }^{131} \mathrm{I}$ (284.3, 364.5, 637.0 , and $722.9 \mathrm{keV}),{ }^{132} \mathrm{Te}(228.2 \mathrm{keV}),{ }^{137} \mathrm{Cs}(661.7$ $\mathrm{keV}),{ }^{134 \mathrm{~g}} \mathrm{Cs}(563.2,569.3,604.7,795.6$, and $802.0 \mathrm{keV})$, and ${ }^{136 \mathrm{~g}} \mathrm{Cs}(340.5$ and $818.5 \mathrm{keV})$ are very intense, since they have high release probabilities. The peaks of refractory elements such as ${ }^{110 \mathrm{~m}} \mathrm{Ag}(657.8,763.9$, and 884.7 $\mathrm{keV}),{ }^{99 \mathrm{~m}} \mathrm{Tc}(140.5 \mathrm{keV}),{ }^{99} \mathrm{Mo}(739.5 \mathrm{keV})$, and ${ }^{95 \mathrm{~g}} \mathrm{Nb}$ $(765.8 \mathrm{keV})$ are also found in the spectrum. Other elements such as ${ }^{95} \mathrm{Zr}$ (half-life $\left.T_{1 / 2}=64.02 \mathrm{~d}\right),{ }^{103} \mathrm{Ru}\left(T_{1 / 2}=\right.$ $39.26 \mathrm{~d}),{ }^{106} \mathrm{Ru}\left(T_{1 / 2}=373.59 \mathrm{~d}\right),{ }^{141} \mathrm{Ce}\left(T_{1 / 2}=32.501 \mathrm{~d}\right)$, and ${ }^{144} \mathrm{Ce}\left(T_{1 / 2}=284.893 \mathrm{~d}\right)$, which were detected in the fallout from the Chernobyl accident in 1986 (Devell et al., 1986; Arvela et al., 1990), were below the detection limits in the course of our measurements, though Kanai (2012) observed trace amounts of ${ }^{141} \mathrm{Ce}$ and ${ }^{144} \mathrm{Ce}$ in the dust sample collected from June 9 to 13, 2011 at Geological Survey of Japan (GSJ), National Institute of Advanced Industrial Science and Technology, Tsukuba, Ja- 
Table 1. Radionuclides identified in this work and their nuclear data

\begin{tabular}{llcr}
\hline Nuclide & Half-life & $\gamma$-ray energy $(\mathrm{keV})$ & $\gamma$-ray abundance \\
\hline${ }^{140} \mathrm{La}$ & $1.6781 \mathrm{~d}$ & 1596.2 & 0.9540 \\
${ }^{140} \mathrm{Ba}$ & $12.752 \mathrm{~d}$ & 537.3 & 0.2439 \\
${ }^{137} \mathrm{Cs}$ & $30.07 \mathrm{y}$ & 661.7 & 0.85 \\
${ }^{136 \mathrm{~g}} \mathrm{Cs}$ & $13.16 \mathrm{~d}$ & 818.5 & 1.0 \\
${ }^{134 \mathrm{~g}} \mathrm{Cs}$ & $2.0648 \mathrm{y}$ & 604.7 & 0.9762 \\
${ }^{133 \mathrm{~g}} \mathrm{I}$ & $20.8 \mathrm{~h}$ & 529.9 & 0.87 \\
${ }^{132 \mathrm{~g}} \mathrm{I}$ & $2.295 \mathrm{~h}$ & 667.7 & 0.987 \\
${ }^{132} \mathrm{Te}$ & $3.204 \mathrm{~d}$ & 228.2 & 0.88 \\
${ }^{131} \mathrm{I}$ & $8.02070 \mathrm{~d}$ & 364.5 & 0.817 \\
${ }^{131 \mathrm{~m}} \mathrm{Te}$ & $30 \mathrm{~h}$ & $773.7,774.1$ & $0.499,0.007$ \\
${ }^{131 \mathrm{~g}} \mathrm{Te}$ & $25.0 \mathrm{~min}$ & 149.7 & 0.6875 \\
${ }^{129 \mathrm{~m}} \mathrm{Te}$ & $33.6 \mathrm{~d}$ & 695.8 & 0.0299 \\
${ }^{129 \mathrm{~g}} \mathrm{Te}$ & $69.6 \mathrm{~min}$ & 459.6 & 0.077 \\
${ }^{110 \mathrm{~m}} \mathrm{Ag}$ & $249.79 \mathrm{~d}$ & 884.7 & 0.722 \\
${ }^{99 \mathrm{~m}} \mathrm{Tc}$ & $6.01 \mathrm{~h}$ & 140.5 & 0.8906 \\
${ }^{99} \mathrm{Mo}$ & $65.94 \mathrm{~h}$ & 739.5 & 0.1213 \\
${ }^{95 \mathrm{~g}} \mathrm{Nb}$ & $34.975 \mathrm{~d}$ & 765.8 & 0.9981 \\
\hline
\end{tabular}

pan (latitude $36.06^{\circ}$ north and longitude $140.13^{\circ}$ east), located about $170 \mathrm{~km}$ to the south-southwest of FDNPP.

In this work, radioactivity concentrations were evaluated for eleven radionuclides of ${ }^{140} \mathrm{Ba},{ }^{137} \mathrm{Cs},{ }^{136 \mathrm{~g}} \mathrm{Cs}$, ${ }^{134 \mathrm{~g}} \mathrm{Cs},{ }^{133 \mathrm{~g}} \mathrm{I},{ }^{132} \mathrm{Te},{ }^{131} \mathrm{I},{ }^{129 \mathrm{~m}} \mathrm{Te},{ }^{110 \mathrm{~m}} \mathrm{Ag},{ }^{99} \mathrm{Mo}$, and ${ }^{95 \mathrm{~g}} \mathrm{Nb}$. The half-lives, $\gamma$-ray energies and abundances used in the radioactivity calculation are listed in Table 1 . We first obtained count rates in the photopeak energy region of interest with the Covell method (Covell, 1959). We corrected the count rates for decays between the end of the air dust collection and the start of the counting and during the counting period, using the half-life values in Table 1 , to obtain the radioactivity concentrations at the end of the sampling. We did not add corrections for decays during the sample collection, because the time structure of the arrival of the radioactive atoms were unknown. The radioactivity concentrations thus obtained are listed in unit of $\mathrm{mBq} \mathrm{m} \mathrm{m}^{-3}$ in Table A1 of Supplementary Materials. The errors given in Table A1 include those from counting statistics and the detector efficiency calibration (2-10\%). The systematic errors associated with the air volume measurements $(<3 \%)$ are not included. For the cases in which the statistical significance of the extracted signal counts is less than $3 \sigma$, the values are listed in italic characters in Table A1, suggesting the practical level of the detection limits with our counting setup.

\section{DISCUSSION}

\section{Radioactivity concentrations}

The time variations of the radioactivity concentrations of ${ }^{137} \mathrm{Cs},{ }^{136 \mathrm{~g}} \mathrm{Cs},{ }^{134 \mathrm{~g}} \mathrm{Cs},{ }^{132} \mathrm{Te},{ }^{129 \mathrm{~m}} \mathrm{Te},{ }^{131} \mathrm{I},{ }^{140} \mathrm{Ba},{ }^{110 \mathrm{~m}} \mathrm{Ag}$, ${ }^{99} \mathrm{Mo}$, and ${ }^{95 \mathrm{~g}} \mathrm{Nb}$ are shown in Figs. 2(a)-(j), respectively,

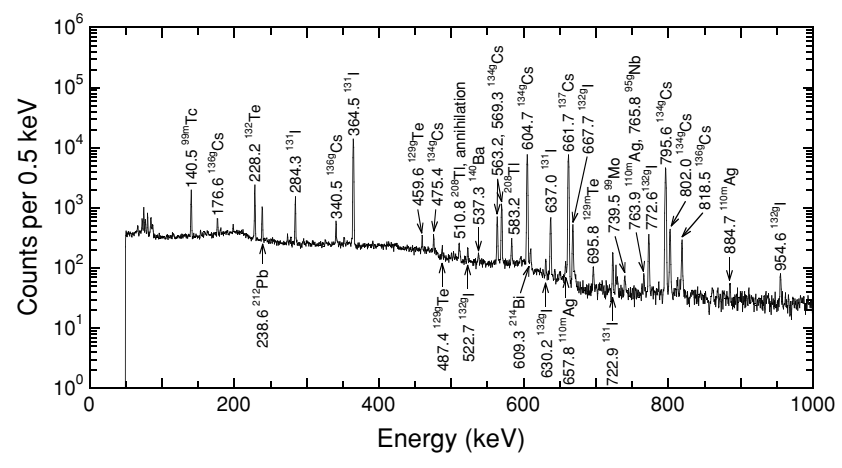

Fig. 1. The gamma-ray spectrum of the air dust sample collected in the period March 29 9:40-March 30 11:15 (JST). The air dust sample was measured with the Ge detector with a relative efficiency of $40 \%$ for 35866 s, starting at 1353 s after the end of the sampling. The gamma lines of 238.6, 510.8, 583.2, and $609.3 \mathrm{keV}$ are due to ${ }^{212} \mathrm{~Pb},{ }^{208} \mathrm{Tl},{ }^{208} \mathrm{Tl}$, and ${ }^{214} \mathrm{Bi}$, respectively, which are descendants of the natural radionuclides ${ }^{210,222} \mathrm{Rn}$ in the atmosphere.

at the end of sampling as reference date. In Fig. 2, we compare the radioactivity concentrations reported by Amano et al. (2012) at JCAC and by Kanai (2012) at GSJ. We corrected the reported radioactivity concentrations by Amano et al. (2012) for radioactive decays in the same manner as described above. Since the radioactivity concentrations at GSJ were reported at the time when aerosol sampling started (Kanai, 2012), we corrected them to those at the end of sampling for better comparisons in Fig. 2. Also noted is that the data of GSJ are for particulate (not gaseous) radionuclides in aerosols (Kanai, 2012). The variations of the radioactivity concentrations are similar among RIKEN, JCAC, and GSJ, though the detailed comparisons are impossible because of the time differences in the sample collections.

As shown in Fig. 2, the highest radioactivity concentrations at RIKEN were observed for all nuclides for the sample collected in the period of March 15 11:15-11:45 (F01). The highest concentrations in $\mathrm{Bq} \mathrm{m}^{-3}$ were $8.8 \pm$ 0.2 for ${ }^{137} \mathrm{Cs}, 1.2 \pm 0.2$ for ${ }^{136 \mathrm{~g}} \mathrm{Cs}, 8.5 \pm 0.2$ for ${ }^{134 \mathrm{~g}} \mathrm{Cs}, 58$ \pm 2 for ${ }^{132} \mathrm{Te}, 8.0 \pm 1.2$ for ${ }^{129 \mathrm{~m}} \mathrm{Te}, 35 \pm 1$ for ${ }^{131} \mathrm{I}, 0.55 \pm$ 0.16 for ${ }^{140} \mathrm{Ba}, 0.071 \pm 0.031$ for ${ }^{110 \mathrm{~m}} \mathrm{Ag}, 1.3 \pm 1.1$ for ${ }^{99} \mathrm{Mo}$, and $0.058 \pm 0.031$ for ${ }^{95 \mathrm{~g}} \mathrm{Nb}$, though the data of ${ }^{110 \mathrm{~m}} \mathrm{Ag},{ }^{99} \mathrm{Mo}$, and ${ }^{95 \mathrm{~g}} \mathrm{Nb}$ are accompanied with large statistical errors. Although the radioactivity concentrations decrease with time, one can clearly see two prominent peaks corresponding to March 20-21 (F07) and March 29-31 (F16 and F17) as indicated by dashed lines in Fig. 2. It is noted that a distinct peak corresponding to March 22-23 (F09) is observed only for ${ }^{131} \mathrm{I}$, indicating that the behavior of radioiodine is different from the behaviors of other elements. Information on the gaseous radioiodine is useful to quantify the total radioactivity concentrations 


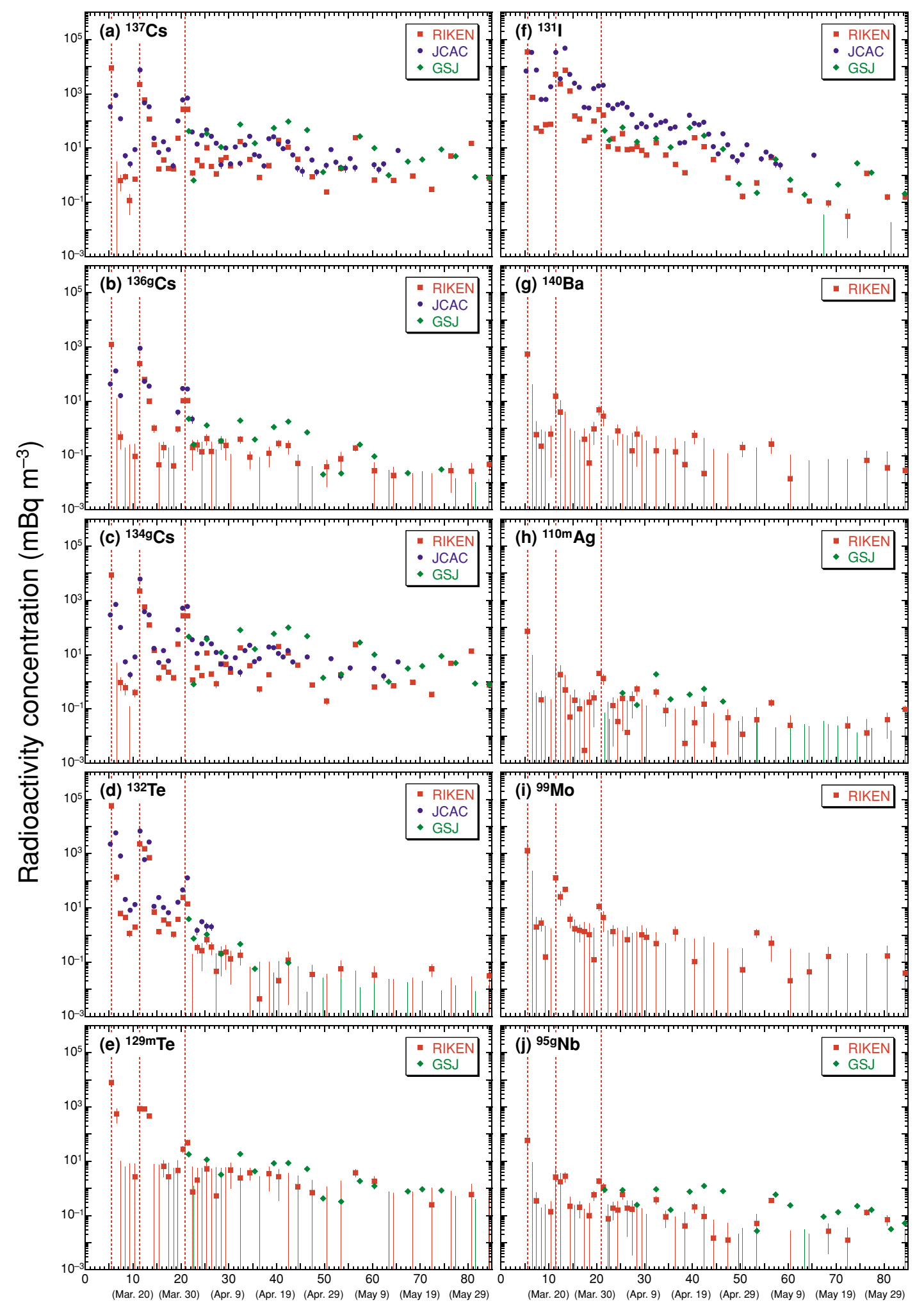

Time since March 10, 2011, 0:00 JST (d)

Fig. 2. Radioactivity concentrations of airborne radionuclides of $(a){ }^{137} \mathrm{Cs},(b){ }^{136 g} \mathrm{Cs},(c){ }^{134 g} \mathrm{Cs},(d){ }^{132} \mathrm{Te},(e){ }^{129 m} \mathrm{Te},(f){ }^{131} \mathrm{I},(\mathrm{g})$ ${ }^{140} \mathrm{Ba},(\mathrm{h}){ }^{110 \mathrm{~m}} \mathrm{Ag},(\mathrm{i}){ }^{99} \mathrm{Mo}$, and $(\mathrm{j}){ }^{95 \mathrm{~g}} \mathrm{Nb}$ at the RIKEN Wako Institute, Wako (this work), Japan Chemical Analysis Center (JCAC), Chiba (Amano et al., 2012), and Geological Survey of Japan (GSJ), Tsukuba (Kanai, 2012). The vertical dashed lines show the times when the measured radioactivity concentration showed notable maximums. For more details see text. 
of radioiodine, however our measurements were only sensitive to radioiodine attached to particles. Amano et al. (2012) measured the ratios of gaseous iodine to total iodine to be 0.71 on March 15-16, 0.52 on March 20-21, and 0.68 on March 22-23 at JCAC, using a cellulose glassfiber filter in combination with an activated charcoal cartridge containing $10 \%$ triethylenediamine. As shown in Fig. 2, the time variations of the radioactivity concentrations of ${ }^{131}$ I are very similar between RIKEN and JCAC. Thus, the total atmospheric radioactivity concentrations of ${ }^{131} \mathrm{I}$ and probably ${ }^{133 \mathrm{~g}} \mathrm{I}$ at RIKEN are estimated to be factors of 2.1-3.4 higher than those measured only for particulate iodine in this work.

In Table A 1 of Supplementary Materials, the radioactivity concentrations of ${ }^{133 \mathrm{~g}} \mathrm{I}$ decreased with time and became below the detection limits after March 22 (F08). The absence of the short-lived ${ }^{133 g} \mathrm{I}\left(T_{1 / 2}=20.8 \mathrm{~h}\right)$ immediately after the earthquake would indicate that nuclear fission reactions in FDNPP was stopped successfully at the time of the earthquake. The radioactivity concentrations of ${ }^{99} \mathrm{Mo}\left(T_{1 / 2}=65.94 \mathrm{~h}\right)$ and ${ }^{132} \mathrm{Te}\left(T_{1 / 2}=3.20 \mathrm{~d}\right)$, which also have relatively short half-lives, were below the detection limits after March 29 (F16) and April 3 (F21), respectively. After June 2 (F45), only ${ }^{137} \mathrm{Cs}$ and ${ }^{134 \mathrm{~g}} \mathrm{Cs}$ with long half-lives of $T_{1 / 2}=30.07 \mathrm{y}$ and $T_{1 / 2}=$ $2.0648 \mathrm{y}$, respectively, were detectable in the atmosphere in Wako. In January-March, 2012, the radioactivity concentrations of ${ }^{137} \mathrm{Cs}$ and ${ }^{134 \mathrm{~g}} \mathrm{Cs}$ decreased to $20-40$ and $10-30 \mu \mathrm{Bq} \mathrm{m}^{-3}$, respectively. This concentration level of ${ }^{137} \mathrm{Cs}$ was still two orders of magnitude higher than those before the FDNPP accident (sub- $\mu \mathrm{Bq} \mathrm{m}{ }^{-3}$ level in Tsukuba, Japan); ${ }^{134} \mathrm{Cs}$ had not been measured in the atmosphere since the end of the 1990s (Igarashi et al., 1999).

\section{Radioactivity ratios}

The radioactivity ratios of ${ }^{136 \mathrm{~g}} \mathrm{Cs},{ }^{134 \mathrm{~g}} \mathrm{Cs},{ }^{132} \mathrm{Te},{ }^{129 \mathrm{~m}} \mathrm{Te}$, ${ }^{131} \mathrm{I},{ }^{140} \mathrm{Ba},{ }^{110 \mathrm{~m}} \mathrm{Ag},{ }^{99} \mathrm{Mo},{ }^{95 \mathrm{~g}} \mathrm{Nb}$ to ${ }^{137} \mathrm{Cs}$ were calculated using the data whose statistical significances are higher than $3 \sigma$. The time variations of the radioactivity ratios are shown in Fig. 3. In the figure, we fitted the ratios $r(t)$ at time $t$ with a simple exponential decay curve,

$$
r(t)=r(0) \exp \left[-\left(\lambda_{1}-\lambda_{2}\right) t\right]
$$

where $\lambda_{1}$ is a decay constant of the radionuclide of interest and $\lambda_{2}$ is the decay constant of ${ }^{137} \mathrm{Cs}$. The ratios between the radionuclides of the identical element, ${ }^{136 \mathrm{~g}} \mathrm{Cs} /$ ${ }^{137} \mathrm{Cs}$ and ${ }^{134 \mathrm{~g}} \mathrm{Cs} /{ }^{137} \mathrm{Cs}$, are nicely described by this fit, indicating that the radiocaesium particles came from the same source. The ${ }^{110 \mathrm{~m}} \mathrm{Ag} /{ }^{137} \mathrm{Cs}$ ratio also follows the fit, though only two data points are available. The ${ }^{134 \mathrm{~g}} \mathrm{Cs} /$ ${ }^{137} \mathrm{Cs}$ ratio has been often used as an indicator to distinguish between the fallout of a nuclear bomb and a power reactor, and further to trace their origins (Biegalski et al.,

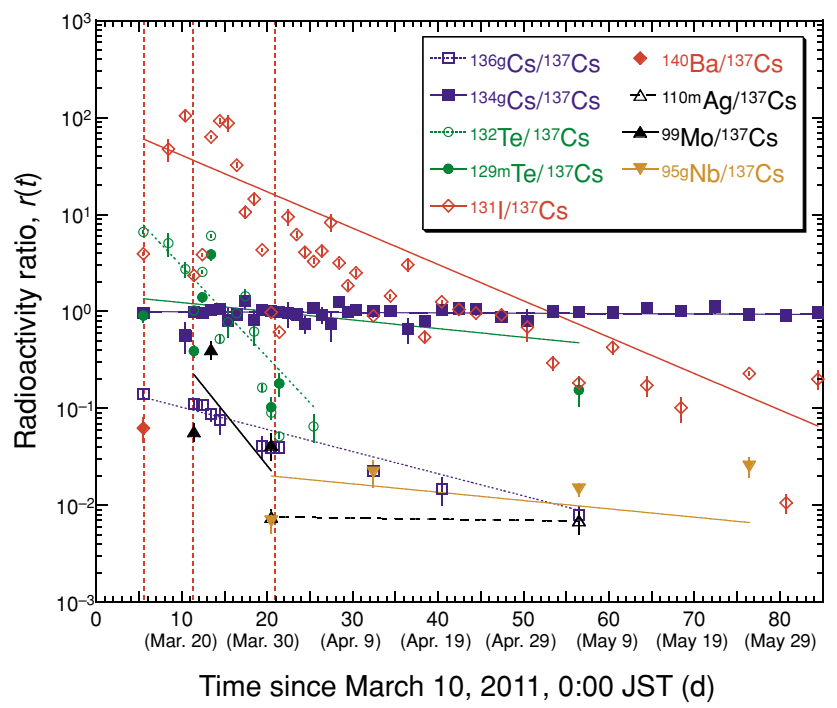

Fig. 3. Time variation of the radioactivity ratios of ${ }^{136 g} \mathrm{Cs}$, ${ }^{134 g} \mathrm{Cs},{ }^{132} \mathrm{Te},{ }^{129 m} \mathrm{Te},{ }^{131} \mathrm{I},{ }^{140} \mathrm{Ba},{ }^{110 m} \mathrm{Ag},{ }^{99} \mathrm{Mo}$, and ${ }^{95 g} \mathrm{Nb}$ to ${ }^{137} \mathrm{Cs}$. The symbols show the measurement results, and the lines show the best fit to the data by Eq. (1) with decay constants of the nuclides.

2012). Our ${ }^{134 \mathrm{~g}} \mathrm{Cs} /{ }^{137} \mathrm{Cs}$ ratio is calculated to be $1.0 \pm 0.1$ for March 11, 2011, and this value is consistent with other observations $(\sim 1)$ related to the FDNPP accident (Diaz Leon et al., 2011; Masson et al., 2011; Kanai, 2012; Huh et al., 2012; Aoyama et al., 2012; Oura and Ebihara, 2012). For comparison, this ${ }^{134 \mathrm{~g}} \mathrm{Cs} /{ }^{137} \mathrm{Cs}$ ratio is twice of that $(\sim 0.5)$ in the Chernobyl fallout in 1986 (Devell et al., 1986; Aoyama et al., 1987; Aoyama, 1988; Arvela et al., 1990). On the other hand, the ${ }^{132} \mathrm{Te} /{ }^{137} \mathrm{Cs},{ }^{129 \mathrm{~m}} \mathrm{Te} /$ ${ }^{137} \mathrm{Cs},{ }^{131} \mathrm{I} /{ }^{137} \mathrm{Cs},{ }^{99} \mathrm{Mo} /{ }^{137} \mathrm{Cs}$, and ${ }^{95 \mathrm{~g}} \mathrm{Nb} /{ }^{137} \mathrm{Cs}$ ratios show large deviations from the fit, implying the different release and transport efficiencies from those of caesium. According to a preliminary estimation on the released radioactivity from FDNPP (Chino et al., 2011), the ratios of the released ${ }^{131} \mathrm{I} /{ }^{137} \mathrm{Cs}$ varied in the range of $1.1-131$ during the period from March 14 to April 5, and the high ${ }^{131} \mathrm{I} /{ }^{137} \mathrm{Cs}$ ratios were 70 and $80-131$ in the periods March 15 15:00-March 17 6:00 and March 21 3:00-March 24 0:00, respectively. From March 14 to April 5, the ${ }^{131} \mathrm{I} /$ ${ }^{137} \mathrm{Cs}$ radioactivity ratios at JCAC varied between 3.0 and 350 , and the high ${ }^{131} \mathrm{I} /{ }^{137} \mathrm{Cs}$ ratios of $240-210$ and 140 350 were observed in the samples collected in March 18 10:05-March 20 10:00 and March 22 9:55-March 25 9:35, respectively (Amano et al., 2012). At RIKEN, the ${ }^{131} \mathrm{I} /$ ${ }^{137} \mathrm{Cs}$ ratios were between 0.61 (F17) and 100 (F06), and the high ratios were registered almost at the same time as JCAC: 100 in March 19 10:05-March 20 10:00 (F06) and 63-88 in March 22 10:05-March 25 9:55 (F09-F11). Our ${ }^{131} \mathrm{I} /{ }^{137} \mathrm{Cs}$ ratios, after the corrections by factors of $2.1-$ 


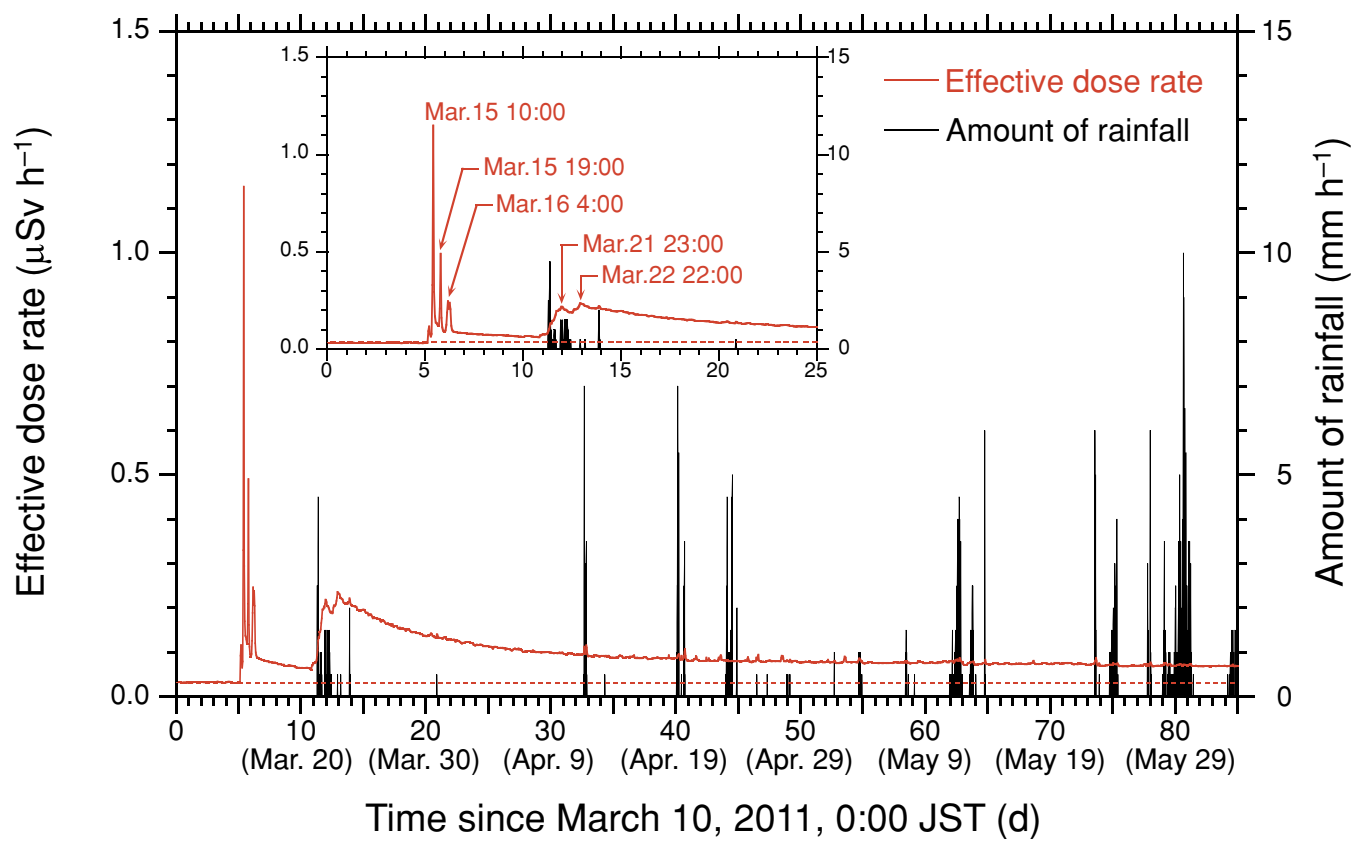

Fig. 4. Effective dose rate and amount of rainfall measured at the RIKEN Wako Institute in 2011. A dashed line is the average effective dose rate of $0.03 \mu \mathrm{Sv} \mathrm{h}^{-1}$ before the Fukushima Dai-ichi nuclear power plant accident in 2011. Inset shows the variation for 0-25 days since March 10, 2011, 0:00 JST.

3.4 for the total atmospheric radioiodine as mentioned above, are almost the same as those at JCAC. The relatively high ${ }^{131} \mathrm{I} /{ }^{137} \mathrm{Cs}$ ratios at JCAC and RIKEN compared with those released from FDNPP (Chino et al., 2011) would be due to higher transport efficiencies of volatile radioiodine than those of radiocaesium. It is also interesting to find that the ${ }^{131} \mathrm{I} /{ }^{137} \mathrm{Cs}$ ratios are very small, 3.9 (F01), 2.4 (F07), and 0.98-0.61 (F16-F17), when the radioactivity concentrations show the maximums (see vertical dashed lines in Fig. 3).

\section{Effective dose rate and amount of rainfall}

Figure 4 shows the time variation of the effective dose rate and the amount of rainfall measured at the RIKEN Wako Institute. On March 15, 2011, the effective dose rate increased from the usual value of $\sim 0.03 \mu \mathrm{Sv} \mathrm{h}^{-1}$ at 4:00 to the maximum of $1.2 \mu \mathrm{Sv} \mathrm{h}^{-1}$ at $10: 00$, and decreased to $0.17 \mu \mathrm{Sv} \mathrm{h}^{-1}$ at 12:00. During this peak, our first air dust sample (F01) was collected for $30 \mathrm{~min}$ at 11:15-11:45. The peak was followed by two separate peaks with the maximum dose rates of 0.49 and $0.25 \mu \mathrm{Sv}$ $\mathrm{h}^{-1}$ on March 15 at 19:00 and on March 16 at 4:00, respectively. At JCAC, Chiba, the first increase of the ambient dose rate was observed at the same time on March 15 at 4:00, and the maximum was $0.5 \mu \mathrm{Gy} \mathrm{h}^{-1}$ at 15:00 (Nagaoka et al., 2012); the gray (Gy) is the SI equivalent of the air kerma. During this period, Nagaoka et al. (2012) observed ${ }^{133 \mathrm{~m}} \mathrm{Xe},{ }^{133 \mathrm{~g}} \mathrm{Xe},{ }^{135} \mathrm{Xe},{ }^{131} \mathrm{I}$, and ${ }^{132} \mathrm{I}$ by the in- situ $\gamma$-ray measurement with the Ge detector and reported that ${ }^{133} \mathrm{Xe}$ was overwhelmingly dominant on March 15 at 15:00. Although the peak of the dose rate observed at RIKEN on March 15 at 19:00 was not observed at JCAC, there was a noticeable increase on March 16 at 9:00, where ${ }^{133 \mathrm{~m}} \mathrm{Xe},{ }^{133 \mathrm{~g}} \mathrm{Xe},{ }^{131} \mathrm{I}$, and ${ }^{132} \mathrm{I}$ were the main contributors (Nagaoka et al., 2012). At RIKEN, Otsu et al. (2012) also conducted the in-situ $\gamma$-ray measurement with the Ge detector and found that the increase of the effective dose rate in the morning of March 16 correlated to the arrivals of radioxenon $\left({ }^{133 \mathrm{~m}} \mathrm{Xe},{ }^{133 g} \mathrm{Xe}\right.$, and $\left.{ }^{135} \mathrm{Xe}\right)$. On March 20 at 21:00, the effective dose rate at RIKEN again started to increase, and reached to the broad peaks of $0.22 \mu \mathrm{Sv}$ $\mathrm{h}^{-1}$ on March 21 at 23:00, and further of $0.24 \mu \mathrm{Sv} \mathrm{h}^{-1}$ on March 22 at 22:00. After these peaks, the effective dose rate decreased with time and became an almost stable value of $\sim 0.08 \mu \mathrm{Sv} \mathrm{h}^{-1}$ two months after the FDNPP accident. The rate of this decrease $\left(T_{1 / 2}=\sim 7 \mathrm{~d}\right)$ is very close to the half-life of ${ }^{131} \mathrm{I}\left(T_{1 / 2}=8.02070 \mathrm{~d}\right)$, indicating that ${ }^{131}$ I was the main decreasing component in the effective dose rate. The effective dose rate at RIKEN was still $\sim 0.06$ $\mu \mathrm{Sv} \mathrm{h}{ }^{-1}$ one year after the accident, and this value was about twice of that before the FDNPP accident (see a dashed line in Fig. 4). The main constituents in the effective dose rate one year after the accident were ${ }^{137} \mathrm{Cs}$ and ${ }^{134 \mathrm{~g}} \mathrm{Cs}$ with long half-lives of $T_{1 / 2}=30.07 \mathrm{y}$ and $T_{1 / 2}=$ $2.0648 \mathrm{y}$, respectively. The accumulated effective dose at the RIKEN Wako Institute was estimated to be $0.65 \mathrm{mSv}$ 
during a year from March 15, 2011 to March 15, 2012, including the exposure from natural background.

The first rainfall after the FDNPP accident was observed on March 21 at 7:00 at the RIKEN Wako Institute. With this rainfall, the effective dose rate rapidly increased as shown in Fig. 4. The atmospheric radioactivity concentrations in March 20-22 (F07 and F08) showed the prominent peak in Fig. 2. This was probably caused by the washout and concentration of airborne radionuclides by the rain. Another peak of the radioactivity concentrations on March 29-31 (F16 and F17) did not correlate well with the effective dose rate as well as the rainfall. Thus, the environmental radioactive contamination in the Wako area occurred mainly on March 21, 2011 by the first rainfall after the accident.

\section{Conclusions}

Airborne radionuclides of ${ }^{140} \mathrm{La},{ }^{140} \mathrm{Ba},{ }^{137} \mathrm{Cs},{ }^{136 \mathrm{~g}} \mathrm{Cs}$, ${ }^{134 \mathrm{~g}} \mathrm{Cs},{ }^{133 \mathrm{~g}} \mathrm{I},{ }^{132 \mathrm{~g}} \mathrm{I},{ }^{132} \mathrm{Te},{ }^{131} \mathrm{I},{ }^{131 \mathrm{~m}} \mathrm{Te},{ }^{131 \mathrm{~g}} \mathrm{Te},{ }^{129 \mathrm{~m}} \mathrm{Te},{ }^{129 \mathrm{~g}} \mathrm{Te}$, ${ }^{110 \mathrm{~m}} \mathrm{Ag},{ }^{99 \mathrm{~m}} \mathrm{Tc},{ }^{99} \mathrm{Mo}$, and ${ }^{95 \mathrm{~g}} \mathrm{Nb}$ from the FDNPP accident on March 11, 2011 were detected at the RIKEN Wako Institute, Wako, Japan, about $220 \mathrm{~km}$ to the southwest of FDNPP. The highest radioactivity concentrations were observed in the sample collected in the period of March 15, 2011, 11:15-11:45. The highest concentrations in Bq $\mathrm{m}^{-3}$ were $8.8 \pm 0.2$ for ${ }^{137} \mathrm{Cs}, 1.2 \pm 0.2$ for ${ }^{136 \mathrm{~g}} \mathrm{Cs}, 8.5 \pm$ 0.2 for ${ }^{134 \mathrm{~g}} \mathrm{Cs}, 4.7 \pm 0.3$ for ${ }^{133 \mathrm{~g}} \mathrm{I}, 58 \pm 2$ for ${ }^{132} \mathrm{Te}, 8.0 \pm$ 1.2 for ${ }^{129 \mathrm{~m}} \mathrm{Te}, 35 \pm 1$ for ${ }^{131} \mathrm{I}, 0.55 \pm 0.16$ for ${ }^{140} \mathrm{Ba}, 0.071$ \pm 0.031 for ${ }^{110 \mathrm{~m}} \mathrm{Ag}, 1.3 \pm 1.1$ for ${ }^{99} \mathrm{Mo}$, and $0.058 \pm 0.031$ for ${ }^{95 \mathrm{~g}} \mathrm{Nb}$. The radioactivity concentrations of the shortlived ${ }^{133 g} \mathrm{I}$ decreased with time and immediately became under the detection limits after March 22, 2011, probably indicating that nuclear fission reactions in FDNPP was successfully stopped at the time of the earthquake. The ${ }^{134 \mathrm{~g}} \mathrm{Cs} /{ }^{137} \mathrm{Cs}$ radioactivity ratio was determined to be 1.0 \pm 0.1 for March 11, 2011, and this value was similar to values measured elsewhere for the FDNPP accident. The environmental radioactive contamination in Wako occurred mainly on March 21, 2011, due to the first rainfall after the accident. After a year, the increased effective dose rate in Wako $\left(\sim 0.06 \mu \mathrm{Sv} \mathrm{h}^{-1}\right)$ was still twice of that before the accident. Our data, together with the measurements from other monitoring stations around the world, will hopefully provide information on the characteristics of the FDNPP accident such as damages of the nuclear reactor, fuel condition, release mechanisms of radionuclides, and their transport throughout the world.

Acknowledgments - We are grateful to Dr. H. Kikunaga from Research Center for Electron Photon Science, Tohoku University for preparation of the $\gamma$-ray standard sources. We also thank Mr. S. Hashiguchi of RIKEN Nishina Center for his compilation of the rainfall data.

\section{REFERENCES}

Amano, H., Akiyama, M., Chunlei, B., Kawamura, T., Kishimoto, T., Kuroda, T., Muroi, T., Odaira, T., Ohta, Y., Takeda, K., Watanabe, Y. and Takao, M. (2012) Radiation measurements in the Chiba metropolitan area and radiological aspects of fallout from the Fukushima Dai-ichi Nuclear Power Plants accident. J. Environ. Radioact. 111, 42-52.

Aoyama, M. (1988) Evidence of stratospheric fallout of caesium isotopes from the Chernobyl accident. Geophys. Res. Lett. 15, 327-330.

Aoyama, M., Hirose, K. and Sugimura, Y. (1987) Deposition of gamma-emitting nuclides in Japan after the Reactor-IV at Chernobyl. J. Radioanal. Nucl. Chem. 16, 291-306.

Aoyama, M., Tsumune, D., Uematsu, M., Kondo, F. and Hamajima, Y. (2012) Temporal variation of ${ }^{134} \mathrm{Cs}$ and ${ }^{137} \mathrm{Cs}$ activities in surface water at stations along the coastline near the Fukushima Dai-ichi Nuclear Power Plant accident site, Japan. Geochem. J. 46, this issue, 321-325.

Arvela, H., Markkanen, M. and Lemmelä, H. (1990) Mobile survey of environmental gamma radiation and fall-out levels in Finland after the Chernobyl accident. Radiat. Prot. Dosim. 32, 177-184.

Biegalski, S. R., Bowyer, T. W., Eslinger, P. W., Friese, J. A., Greenwood, L. R., Haas, D. A., Hayes, J. C., Hoffman, I., Keillor, M., Miley, H. S. and Moring, M. (2012) Analysis of data from sensitive U.S. monitoring stations for the Fukushima Dai-ichi nuclear reactor accident. J. Environ. Radioact. (in press).

Browne, E. and Firestone, R. B. (1986) Table of Radioactive Isotopes. John Wiley \& Sons, New York.

Chino, M., Nakayama, H., Nagai, H., Terada, H., Katata, G. and Yamazawa, H. (2011) Preliminary estimation of release amounts of ${ }^{131} \mathrm{I}$ and ${ }^{137} \mathrm{Cs}$ accidentally discharged from the Fukushima Daiichi Nuclear Power Plant into the atmosphere. J. Nucl. Sci. Technol. 48, 1129-1134.

Covell, D. F. (1959) Determination of gamma-ray abundance directly from the total absorption peak. Anal. Chem. 31, 1785-1790.

Devell, L., Tovedal, H., Bergström, U., Appelgren, A., Chyssler, J. and Andersson, L. (1986) Initial observations of fallout from the reactor accident at Chernobyl. Nature 321, 192193.

Diaz Leon, J., Jaffe, D. A., Kaspar, J., Knecht, A., Miller, M. L., Robertson, R. G. H. and Schubert, A. G. (2011) Arrival time and magnitude of airborne fission products from the Fukushima, Japan, reactor incident as measured in Seattle, WA, USA. J. Environ. Radioact. 102, 1032-1038.

Firestone, R. B. and Shirley, V. S. (1996) Table of Isotopes, 8th ed. Wiley, New York.

Huh, C. A., Hsu, S. C. and Lin, C. Y. (2012) Fukushimaderived fission nuclides monitored around Taiwan: Free tropospheric versus boundary layer transport. Earth Planet. Sci. Lett. 319-320, 9-14.

Igarashi, Y., Aoyama, M., Miyao, T., Hirose, K., Komura, K. and Yamamoto, M. (1999) Air concentration of radiocaesium in Tsukuba, Japan following the release from the Tokai waste treatment plant: comparisons of observations with predictions. Appl. Radiat. Isot. 50, 1063-1073. 
Kanai, Y. (2012) Monitoring of aerosols in Tsukuba after Fukushima Nuclear Power Plant incident in 2011. J. Environ. Radioact. 111, 33-37.

Kim, C. K., Byun, J. I., Chae, J. S., Choi, H. Y., Choi, S. W., Kim, D. J., Kim, Y. J., Lee, D. M., Park, W. J., Yim, S. A. and Yun, J. Y. (2012) Radiological impact in Korea following the Fukushima nuclear accident. J. Environ. Radioact. 111, 70-82.

Long, N. Q., Truong, Y., Hien, P. D., Binh, N. T., Sieu, L. N., Giap, T. V. and Phan, N. T. (2012) Atmospheric radionuclides from the Fukushima Dai-ichi nuclear reactor accident observed in Vietnam. J. Environ. Radioact. 111, 53-58.

Masson, O., Baeza, A., Bieringer, J., Brudecki, K., Bucci, S., Cappai, M., Carvalho, F. P., Connan, O., Cosma, C., Dalheimer, A., Didier, D., Depuydt, G., De Geer, L. E., De Vismes, A., Gini, L., Groppi, F., Gudnason, K., Gurriaran, R., Hainz, D., Halldórsson, Ó. Hammond, D., Hanley, O., Holeý, K., Homoki, Zs., Ioannidou, A., Isajenko, K., Jankovic, M., Katzlberger, C., Kettunen, M., Kierepko, R., Kontro, R., Kwakman, P. J. M., Lecomte, M., Leon Vintro, L., Leppänen, A.-P., Lind, B., Lujaniene, G., Mc Ginnity, P., Mc Mahon, C., Malá, H., Manenti, S., Manolopoulou, M., Mattila, A., Mauring, A., Mietelski, J. W., Møller, B., Nielsen, S. P., Nikolic, J., Overwater, R. M. W., Pálsson, S. E., Papastefanou, C., Penev, I., Pham, M. K., Povinec, P. P., Ramebäck, H., Reis, M. C., Ringer, W., Rodriguez, A., Rulík, P., Saey, P. R. J., Samsonov, V., Schlosser, C., Sgorbati, G., Silobritiene, B. V., Söderström, C., Sogni, R., Solier, L., Sonck, M., Steinhauser, G., Steinkopff, T., Steinmann, P., Stoulos, S., Sýkora, I., Todorovic, D., Tooloutalaie, N., Tositti, L., Tschiersch, J., Ugron, A., Vagena, E., Vargas, A., Wershofen, H. and Zhukova, O. (2011) Tracking of air- borne radionuclides from the damaged Fukushima Dai-ichi nuclear reactors by European networks. Environ. Sci. Technol. 45, 7670-7677.

Momoshima, N., Sugihara, S., Ichikawa, R. and Yokoyama, H. (2012) Atmospheric radionuclides transported to Fukuoka, Japan remote from the Fukushima Dai-ichi nuclear power complex following the nuclear accident. J. Environ. Radioact. 111, 28-32.

Nagaoka, K., Sato, S., Araki, S., Ohta, Y. and Ikeuchi, Y. (2012) Changes of Radionuclides in the environment in Chiba, Japan, after the Fukushima Nuclear Power Plant Accident. Health Phys. 102, 437-442.

Otsu, H. et al. (2012) Radioactive Xe arriving in and passing through Wako area. RIKEN Accel. Prog. Rep. 45 (in press).

Oura, Y. and Ebihara, M. (2012) Radioactivity concentrations of ${ }^{131} \mathrm{I},{ }^{134} \mathrm{Cs}$ and ${ }^{137} \mathrm{Cs}$ in river water in the Greater Tokyo Metropolitan area after the Fukushima Daiichi Nuclear Power Plant Accident. Geochem. J. 46, this issue, 303-309.

Zhang, W., Bean, M., Benotto, M., Cheung, J., Ungar, K. and Ahier, B. (2011) Development of a new aerosol monitoring system and its application in Fukushima nuclear accident related aerosol radioactivity measurement at the CTBT radionuclide station in Sidney of Canada. J. Environ. Radioact. 102, 1065-1069.

\section{SUPPlEMENTARY MATERiAlS}

We present here a table of the sampling periods and the atmospheric radioactivity concentrations of ${ }^{140} \mathrm{Ba}$, ${ }^{137} \mathrm{Cs},{ }^{136 \mathrm{~g}} \mathrm{Cs},{ }^{134 \mathrm{~g}} \mathrm{Cs},{ }^{132} \mathrm{Te},{ }^{133 \mathrm{~g}} \mathrm{I},{ }^{131} \mathrm{I},{ }^{129 \mathrm{~m}} \mathrm{Te},{ }^{110 \mathrm{~m}} \mathrm{Ag}$, ${ }^{99} \mathrm{Mo}$, and ${ }^{95 \mathrm{~g}} \mathrm{Nb}$. URL (http://www.terrapub.co.jp/ journals/GJ/archives/data/46/MS213.pdf). 